\title{
Determinants of Educational Achievement in Morocco: A Micro-Econometric Analysis Applied to the TIMSS Study
}

\author{
Aomar Ibourk $^{1}$ \\ ${ }^{1}$ Faculty of Legal, Economics and Social Sciences, Cadi Ayyad University, Marrakesh, Morocco \\ Correspondence: Aomar Ibourk, Faculty of Legal, Economics and Social Sciences, PO Box 2380 Marrakesh, \\ Morocco. E-mail: aomaribourk@gmail.com
}

Received: September 9, 2013

Accepted: November 19, 2013 Online Published: November 26, 2013

doi:10.5539/ies.v6n12p25

URL: http://dx.doi.org/10.5539/ies.v6n12p25

\begin{abstract}
Based on data from international surveys measuring learning (TIMSS), this article focuses on the analysis of the academic performance Moroccan students. The results of the econometric model show that the students' characteristics, their family environment and school context are key determinants of these performances. The study also shows that the Moroccan educational system is segmented: urban versus rural and public versus private. This double duality illustrates clearly that the Moroccan education system is a juxtaposition of a "categories" rather than a "unified" market.
\end{abstract}

Keywords: Morocco, education, academic achievement, TIMSS, quantiles regressions

\section{Introduction}

Since its independence in 1956, Morocco claims an economic development model that seeks to upgrade the national economy from a dual economy to a market economy sufficiently structured in order to integrate into the dynamic of globalization. Strategic choices, in term of economic policies, initiated in Morocco these last two decades are all oriented towards the strengthening of this model. Structural reforms, integration of national economy to free trade zones with strategic partners, launch of structuring investment projects as well as obtaining an advanced status with the EU illustrate perfectly the political will to make this development project concrete.

Despite this will, however, human resources are definitely the Achilles' heel of Moroccan economy. This fact threats seriously the concretization of the development model claimed by Moroccan policy makers. Having inherited an embryonic educational system from the Protectorate era, Morocco tried, since its independence, to develop its education so as to face a twofold challenge related not only to extension but also to upgrading. Many achievements can be noted in formal education as well as in informal one (Ibourk, 2010, 2011) taking into account the fact that the population size has almost tripled going from 11 million to 30 million. Actually, Morocco has managed to improve relatively education's indicators. At the dawn of the independence, most Moroccan children were not enrolled in primary school, only $2.8 \%$ of the population, at that time, were enrolled (Barro \& Lee, 2010), in 2010 this rate is estimated at 23.6\%. Nevertheless, this positive evolution remains insufficient when comparing Morocco to other countries with similar development features in the sixties. For instance, the rate of primary school enrollment, in 2010 , is at $28.1 \%$ in Tunisia, $59.7 \%$ in Syria and $38.8 \%$ in Algeria. Regarding informal education, the adjusted net enrollment rate went from $39 \%$ in 1971 to $96 \%$ in 2011 . Moreover, the enrollment rate of children aged from 6 to 11 has earned 6.1 points: 91.4\% pts 2007/2008 against $97.5 \%$ in 2010/2011; and so the access to the first grade is almost generalized. The number of students went from 336,514 in 1955-1956 to almost 7 million in 2010-2011. According to the Secretary of State in charge of education, the gender parity index has improved by increasing nationally and in rural areas respectively by 3 and 5 points reaching 0.90 and 0.88 in 2011 against 0.87 and 0.83 in 2007/2008. Similarly, the rate of dropping decreases in $2010 / 2011$ compared to $2007 / 2008$ by $34.5 \%$ in primary schools, $19 \%$ in middle school and $20.4 \%$ in high-school. On the other hand, the contribution of the private sector remains low with only $12 \%$ of enrollment in primary education and $5.6 \%$ in higher education.

In the light of these statistics, one can easily notice that Moroccan government invests heavily in education. Indeed, $25.7 \%$ of its expenditure is allocated to education approximating $5.5 \%$ of the GDP. Compared to similar countries, Morocco's education expenditure is the highest; however the achievements remain below expectations 
especially when one considers the challenges raised by policy makers and the launch of the National Initiative of Human Development. Furthermore, the problematic of education can be divided into three complementary and interdependent categories: access, retention and learning. The priority to policy makers is to maintain the progress achieved in the access part by streamlining the two other parts which are retention and the quality of learning. Unfortunately, Morocco's score in standardized tests such as TIMSS and PIRLS is very disappointing. This fact urges the need to improve learning quality. In order to achieve this, the scope of analysis should include the internal as well as the external factors that affect schools. Intern quality measures usually the link between educational outcomes and resources allocated to education meanwhile extern quality measures the degree of realizing economic, politic and social objectives related to the education system.

Quality of learning does not depend only on what happens inside the school but depend also on its external environment. Thus, student outcomes are related to several factors inherent, among others, to student's ability, his family background and to the pedagogy adopted. Several actions can be done in order to improve quality of education such as: renewing the curriculum, reforming exams, rehabilitating infrastructures, strengthening parents involvement etc. Hence, this study of student achievements subscribes totally to the next step that should be planned by Moroccan government. The interest is twofold: methodologically, this study is, to my knowledge, the first one to apply a micro-econometric analysis to the subject of educational achievements in Morocco; analytically, this study comes also to complement other rare descriptive studies on the subject (Altinok, 2011). The framing of Moroccan education system reveals that basically two segmentations can be made: the first one is related to urban/rural areas while the second one is linked to public/private sectors. In fact, this shows that the education market is hardly homogenous. Indeed, the latter can be depicted as a juxtaposition of several markets rather than a unified market.

The objective of this study is to examine school such as an entity affected by some phenomena while reproducing them within its classes. At this level, education sociology is driven by three major trends : the first one founded by Durkheim argues that school has to train students to their future tasks besides maintaining social cohesion by teaching them rules, values and social norms. Hence, the survival of a society can be achieved only if "a sufficient homogeneity exists among its members: education perpetuates and enhances this homogeneity by fixing, in advance, in the child soul the similarities that collective life demands Durkheim (1922)". The second trend, called "conflictualist", Bourdieu (1970), introduces a new dimension to education which is the social reproduction. In other words, school has the function of ideological imposition and also the reproduction of the social production reports. The third trend, pioneered by Boudon (1973), includes agents' strategies in its analysis. Indeed, educational success is carried out by different familial strategies. Based on agent's rationality, the choice of a career rely upon the social class of the agent.

This paper analyzes how some factors, such as family background, type of school and even student himself, affect educational achievements. Moreover, the question raised by this paper is how these factors behave among good students, average students and poor students.

The econometric approach proposed in this paper is innovative. However, endogenous variable presents many variations, so linear regression based on the mean estimation is not appropriate. That there is more than a single slope (rate of change) describing the relationship between endogenous variable and exogenous variables. We show in this paper that quantile regression approach which estimates multiple rates of change (slopes) from minimum to maximum response, provide a more complete picture of the relationship between variables missed by linear regression.

The remainder of this paper proceeds as follows. The first section exposes, through a literature review, how education can explain several economic phenomena. The second recalls the main descriptive results. The third section presents the data used as well as the methodology adopted. The fourth section shows the econometric estimations followed by some comments. The last section is dedicated to policy implications and some recommendations.

\section{Quantity vs. Quality: A Literature Review}

In a theoretical framework, education yields to two kinds of returns. The first one is private while the second is social. Put simply, private return belongs to individuals so that every additional year of schooling yields an increase in future income. Furthermore, social return ensures a social cohesion due, among others, to the reduction of criminality, the strengthening of citizenship (improving vote quality, creation of NGOs...). Ideally, social return should exceed private return.

Some of the existing literature argues that a link exists between education and growth as depicted by human capital theory (Mincer, 1958; Shultz, 1960, 1997; Becker, 1964; Denison, 1962, 1979). In order to test this theory, 
education can be defined empirically in terms of quantitative variables as well as qualitative variables.

\subsection{Quantity of Education and Economic Performance}

In a microeconomic framework, the Mincer earnings function (Mincer, 1958, 1974) estimates educational returns, whereas in macroeconomics the link between education and growth has never been proved, at least unanimously. Barro (1991), for instance, found a significant positive relation between initial human capital (rate of enrollment in 1960) and growth. Mankiw, Romer, and Weil (1992) conclude that their results confirm the extended Solow model. Benhabib and Spiegel (1994) estimate a Cobb-Douglas production function in which physical capitals as well as human capital are considered as production factors. Their results revealed that human capital contributes to economic growth throughout two mechanisms. First, the level of human capital influences directly the rate of technological innovation produced locally as found also by Romer (1990). Second, the stock of human capital affects the speed of the adoption of foreign technology; this assertion comes along with the findings of Nelson and Phelps (1966). In a whole, according to the authors, all countries would converge to the same level. Empirically, Amaghouss and Ibourk (2013b) have analyzed recently the effect of quantitative and qualitative indicators of the human capital within MENA countries on economic growth. The results have shown that the effect of education depend on the measure used and on the relevant sub-group.

\subsection{Quality of Education and Economic Performance}

The development of the qualitative approach of education has been initiated mainly in the US. Indeed, the Coleman report (Coleman et al., 1960) is one of the earliest works that established the relationship between educational outcomes and education resources. Moreover, Mulligan (1990) and Lazear (2003) adopted a direct estimation of the impact of achievements obtained in standardized tests. Actually, they used a representative database of individuals, entering to the labor market, who finished their education. Their results suggest that an increase of the standard-error of mathematical achievements increases earnings by $12 \%$. Based on the higher education national survey of 1972, Murnane, Willet, Duhaldeborde, and Tyler (2000) investigate empirically the link between quality of education and individual earnings. Results reveal that earnings for men and for women respectively increase by $15 \%$ and $10 \%$ when the standard-error of the test score increases by $1 \%$. However, the quality of education in developing countries is overlooked. Hanushek and Wößmann (2007) suggest that educational returns observed in developing countries are higher than those observed in developed countries.

Since the 1990's, several empirical works used scores of standardized test in order to test the relation between quality of education and growth. Hanushek and Kimko $(1995,2000)$ constructed an index of education quality, based on standardized tests. Their findings are in favor of the positive relation between education and growth in the 1960-1990 periods. Furthermore, Barro (2001) used several standardized tests and combined it with quantitative indicators of education. He found that both quality and quantity of education have an impact on growth; however quality has a greater impact on economic growth. Wößmann $(2002,2003 a)$ suggests that the proportion of variation in the level of economic development due to human capital increases if the quality of education is considered. Bosworth and Collins (2003); Ciccone and Papaioannou (2005) extend the works of Hanushek and Kimko, their results confirms those of Barro (2001) regarding the importance of the role of education quality on growth.

\section{Morocco's Result in TIMSS}

The TIMSS survey investigates the achievement, in sciences and mathematics, of students enrolled in the fourth and eighth grade. Regarding the test content, a wide range of subject is proposed while the questions are either in a multiple choice framework or just an open question. Moreover, the sample is assumed to be representative of the population even though some schools hosting students with specific needs or those located in remote areas were not included. Ideally, the sample should include 150 schools; however, only 131 schools were included in the Moroccan sample. In addition to the test results, several information were collected, by the means of forms addressed to students, teachers and principals, relate the family background as well as the school climate.

In 2007, TIMSS revealed the low performance of Moroccan students in science and mathematics. Thus, it is not surprising to see Morocco taking the lowest rankings: $34 \mathrm{th} / 36$ place in sciences and $31 \mathrm{th} / 36$ in mathematics. The average score in science reaches 297 pts ( 7 points less than in 2003) whereas the average score in mathematics is around 341 pts ( 6 points less than 2003). When comparing these results to other countries belonging to the MENA, Morocco detains the third highest score in mathematics, lower than Iran (402) and Algeria (378), but does better than Tunisia, Kuwait, Qatar and the Yemen. Being behind Tunisia, Algeria, Iran and the Kuwait, Morocco's rank tends to slightly decrease in sciences, but still manages to do better than Qatar and the Yemen. Put simply, Moroccan score in mathematics is higher than the MENA average but its score in sciences is below the local average. In addition, Iran is the most efficient country in the MENA region in both mathematics and 
sciences while Yemen has the weakest education system in the region.

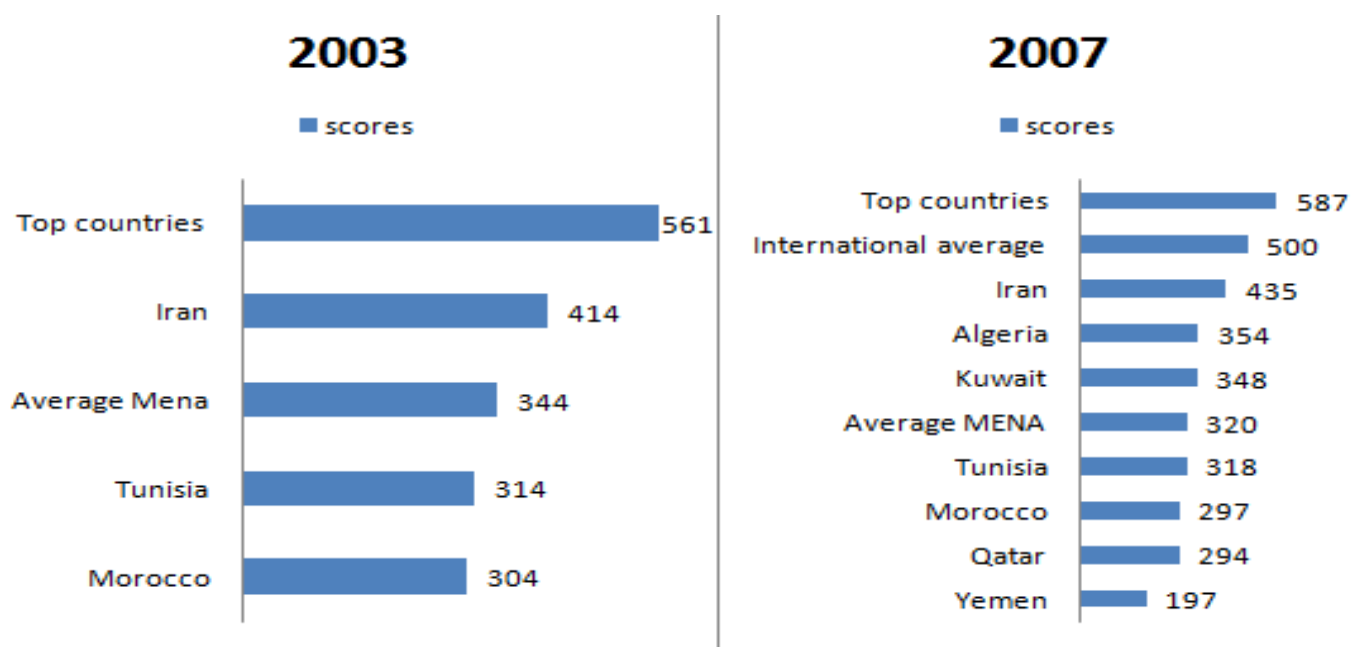

Figure 1. TIMSS Sciences results for the 4th grade. Sources: TIMSS 2003, TIMSS 2007

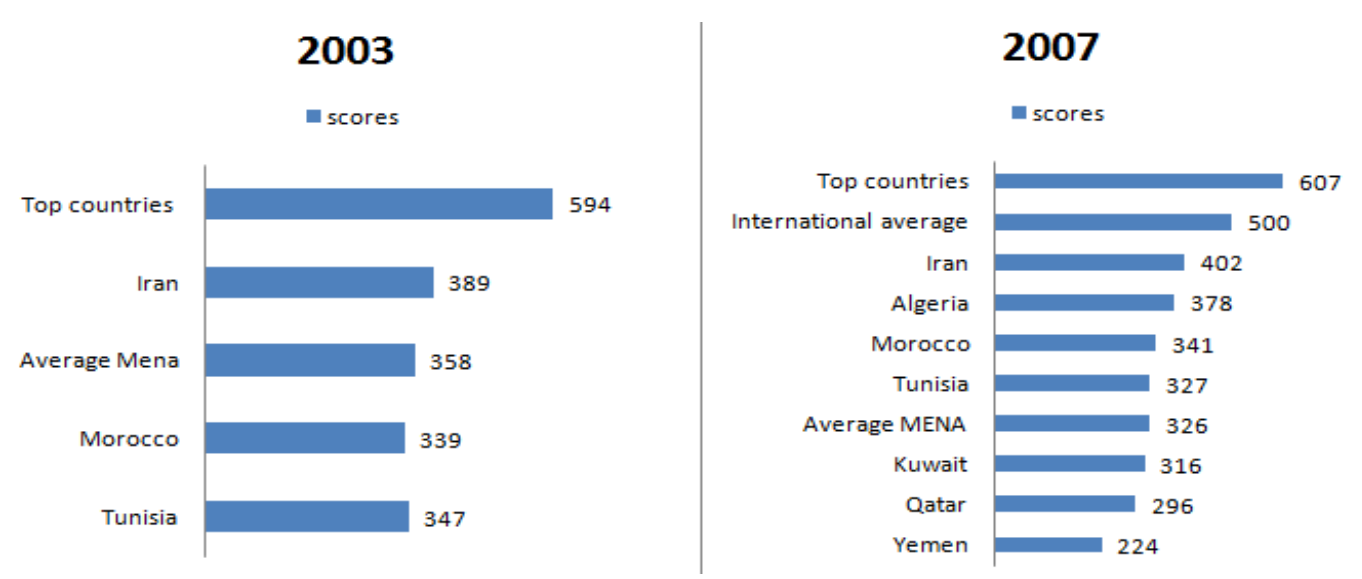

Figure 2. TIMSS Mathematics results for the 4th grad. Source: TIMSS 2003, TIMSS 2007

Concerning the 8 th grade, on the 48 participants, Morocco (381 in mathematics, 402 in sciences) as well as the 14 countries of the MENA detain a score lower than the international mean. Due to Turkey's participation (432 in mathematics, 454 in sciences) to TIMSS, the Moroccan ranking in the region decreases. However, even in a narrower context, the close neighbors of Morocco, namely Algeria (387 in mathematics, 408 in sciences) and Tunisia (420 in mathematics, 445 in sciences) detain a higher score. On the other hand, Lebanon has the most outstanding score in the region in mathematics whereas Jordan ranks first regionally in sciences. The last place is occupied by Qatar both in mathematics and science. 


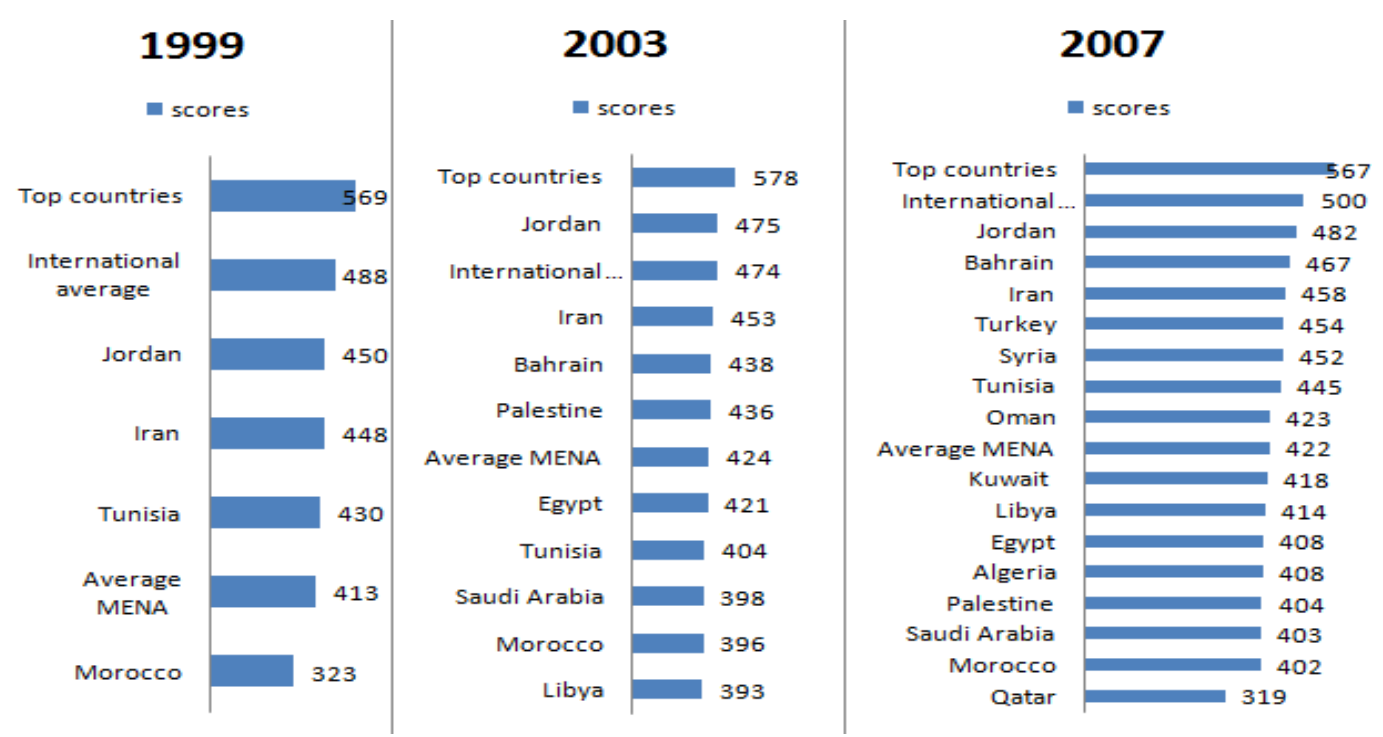

Figure 3. TIMSS Sciences results for the 8th grade. Source: TIMSS 1999, TIMSS 2003,TIMSS 2007

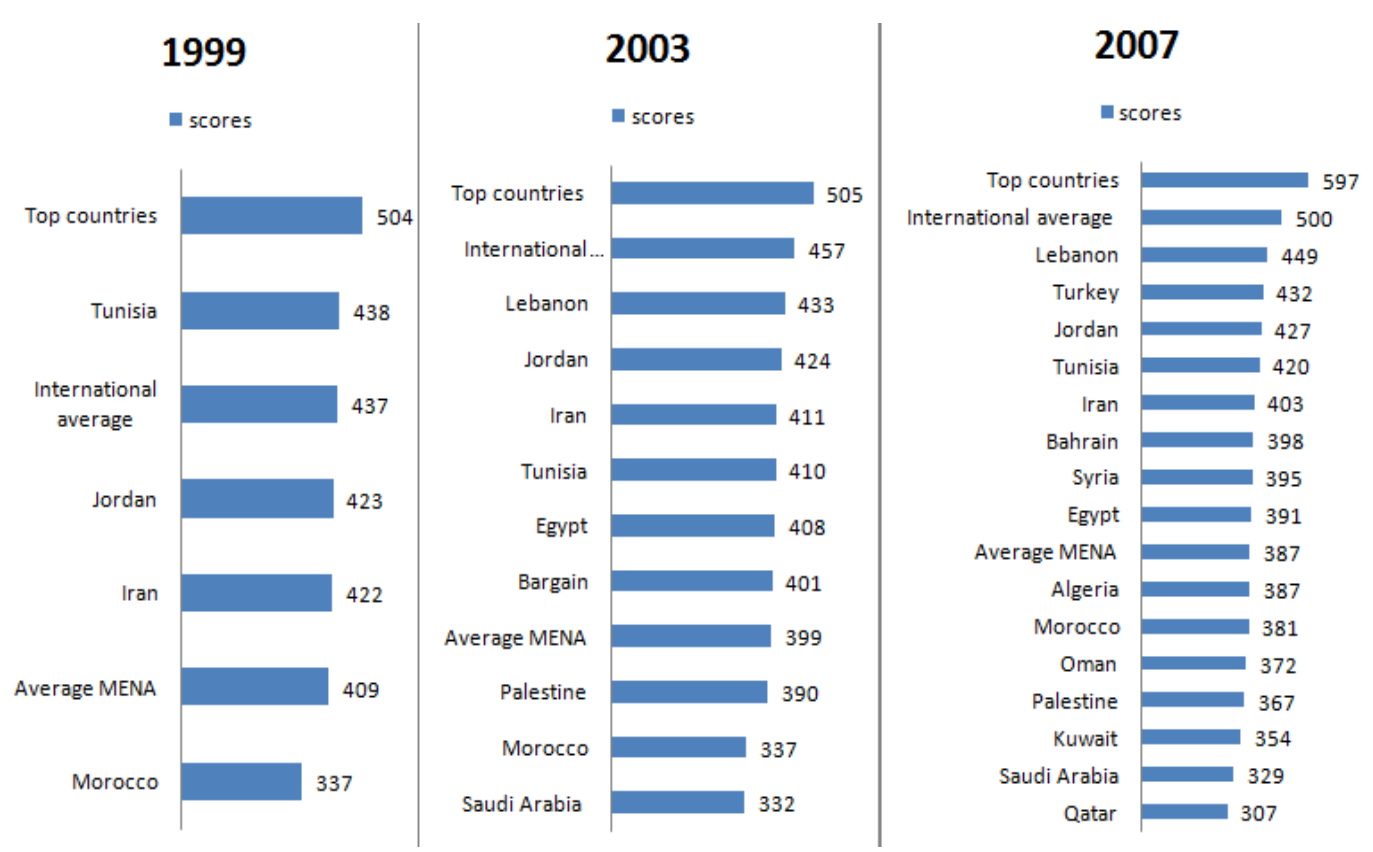

Figure 4. TIMSS Mathematics results for the 8th grade. Source: TIMSS 1999, TIMSS 2003, TIMSS 2007

Graphics 1, 2, 3 and 4 reveal that the most performing countries are located in Asia, doing significantly better than European countries and the US. This fact translates a real investment in education.

\section{Empirical Study}

\subsection{Data and Methodology}

\subsubsection{Data}

The empirical work led uses the TIMSS database. Each observation (student) is described by the following factors:

Student characteristics: For some researchers, difference, in achievement, between students is partly explained by their innate abilities. They consider that educational outcomes are positively correlated to Intellectual 
Quotient (IQ). The genetic trend argues that educational failure is due to some intrinsic deficiencies inherent to the student which can be detected by tests. Debray-Ritzen (1978) affirms that educational success depends upon intelligence which is contained by genetic patrimony. On the other hand, Maehr, Pintrich and Linnenbrink (2002) show that motivation and self-confidence have a tight link with educational success.

Family background: Several works have investigated the impact of family background, with a special focus on cultural heritage. Educational performance is assumed to rely on the linguistic and cultural background of the family. Mingat (1991) found that student achievement is directly dependent upon his social class. Blue collar's children tend to be the poorer students whereas white collar's children tend to get the highest grades.

School climate: Even though, external factors impact heavily educational outcomes, internal ones have also an important role. Factors such Class size (Fuller, 1986; Akoué, 2007), pedagogy adopted (Lockheed \& Verspoor, 1990; Nlep, 2001), facilities (Ouellet, 1987; Psacharapoulos \& Woodhall, 1988) seem to play a role in the explanation of educational achievement.

\subsubsection{Methodology}

The objective is to estimate the impact of exogenous variables on the test scores by means of quantile regression (Koenker \& Bassett, 1978). More specifically, this method allows exploring how covariates affect the whole conditional distribution of the dependent variable. Furthermore, quantile regression does not assume neither homoscedasticity nor normality, thus, the results are more accurate when data contain these features (Hao \& Naiman, 2007). A quantile can be defined as:

Let $\mathrm{Y}$ be a random variable, $\mathrm{Y} \in \mathrm{R}$, distributed as follows: $F(y)=\operatorname{prob}(Y \leq y)$. Holding $0 \prec \tau \prec 1$ :

$$
Q_{\tau}=\inf \{y: F(y) \geq \tau\}
$$

Applying this definition to education, the quantile 0.5 , called median, corresponds to the student who divides the distribution into two equal parts. Hence, half of the students have a higher score than the median student while the second half has a lower score than the median student. Empirically, the quantile regression is formulated as follows:

$$
\begin{gathered}
y_{i}=\beta_{0}^{\tau}+\beta_{1}^{\tau} x_{i}+\varepsilon_{i}^{\tau} \\
Q^{\uparrow} \tau\left(y_{\downarrow} i \mid x_{\downarrow} i \perp\right)=\beta_{\downarrow} 0^{\uparrow} \tau+\beta_{\downarrow} 1^{\uparrow} \tau \quad x_{\downarrow} i
\end{gathered}
$$

where $\mathrm{x}$ is a vector of exogenous variable. The covariates used in the regressions are the age, sex of the student, schooling level of parents, type of school and its location, student's endowments (dictionary, computer at home, desk and internet) and student's characteristics (preparation of homework, self-confidence) while $Q^{\tau}($.$) is the$ conditional quantile function. The regression used in this paper is based on the Koenker and Bassett (1978) article:

$$
Q_{\downarrow} \tau\left(Y_{\downarrow}(i, j, k) \mid X=X^{\prime} \beta^{\uparrow} \tau \perp\right.
$$

The usual quantile regression model assumes exogeneity; however, the context studied is particular since schools interact with its environment. Hence, the problem of endogeneity is omnipresent. Knowing that the variables of TIMSS and PIRLS contain a huge amount of missing data, it is very difficult to adopt methods that fix endogeneity, thus the most that can be said is that adopting this method is rough. It's worth noting that results should be interpreted carefully.

\subsection{Results}

From 2003 to 2007, Morocco's average score has slightly decreased going from 387.1 to 379.29 , whereas the standard deviation has climbed to 73.61 in 2007 far from 60.38 pts observed in 2003. This evolution suggests that Moroccan students' performance didn't vary too much from 2003 to 2007, which is simply not true. 
Table 1. The evolution of students whose score is below 400 points

\begin{tabular}{ccccc}
\hline & \multicolumn{2}{c}{2003} & \multicolumn{2}{c}{2007} \\
\cline { 2 - 5 } & $<400$ & $400<$ & $<400$ & $400<$ \\
\hline National & $59,33 \%$ & $40,67 \%$ & $61,96 \%$ & $38,04 \%$ \\
Rural & $64,76 \%$ & $35,24 \%$ & $81,84 \%$ & $18,16 \%$ \\
Urban & $58,38 \%$ & $41,62 \%$ & $60,03 \%$ & $39,97 \%$ \\
\hline
\end{tabular}

Source: Timss 1999, Timss 2003, Timss 2007.

Before analyzing table 3 , it is important to define the score below the 400 pts. Indeed, 400 points correspond to the numeracy threshold, that is, score falling below this threshold translates an innumeracy case. On the national level, $59.33 \%$ of the students in the sample were identified below that threshold in 2003 , this situation gets even worse in 2007: $61.96 \%$ of the students are below the threshold. This is largely due to the deterioration of rural schools, knowing that $81.84 \%$ of rural students don't understand the rudiments of mathematics.

In order to understand more Morocco's score, the quantile regression is run on three quantile: 0.05 corresponding to the poorer students, 0.5 corresponding to the median students and 0.95 to good students. In addition, An OLS regression is also estimated serving as a benchmark.

The interpretation of student age is of interest, because besides repeating, age reflects also whether the student has been enrolled in preprimary education which is depicted by the literature as a strong factor of improvement in terms of educational achievement. Preprimary education is an investment that entails a high opportunity cost, especially in developing countries where the alternatives are many. Hence, only parents, who value education, would send their children to preprimary establishments. On the other hand, children, who have never been enrolled in a preprimary establishment, enter to school at a late age, not to mention the fact that they spend this wasted time in an environment mostly inappropriate for education.

The "girl" variable translates into a gender gap that affects negatively and significantly girls' score. This finding corroborates those led in African countries such as the works of Hoffman (2001), Ouédraogo and Bance (2001) and Suchaut (2006). The OLS estimation suggests that girls have an average score less than boys by 9.11 points, however the effect is not uniform on the whole conditional distribution as mentioned by quantile regressions: only the better students suffer from the gender gap in ways that the spread is about 24 points much higher than suggested by the OLS. Note that the gender gap is present in almost all countries; nonetheless this phenomenon is amplified in developing countries due to the social role attributed to girls who are confined mainly to household tasks.

On the other side, parents' education does not seem to play a major role in students' performance; it's actually the investments made that affect the scores instead. For instance, possessing a calculator as well as a dictionary improves student's performance. Several works found that, in developing countries, some basic investments, such these, yield to better scores. According to the OLS estimations, possessing a calculator and a dictionary increase the score, in average, respectively by 25.91 and 22.59 . Nevertheless, this relation is by no means homogenous on the whole conditional distribution; regarding calculator, the positive effect is observed only among students, whose performance is low or median, respectively by 30.35 and 28.12 whereas the effect of dictionary affects these two categories of students respectively by 23.59 and 20.15 . Concerning the most performing students, any link with these two investments seems to be established. 
Table 2. Quantile regression: TIMSS

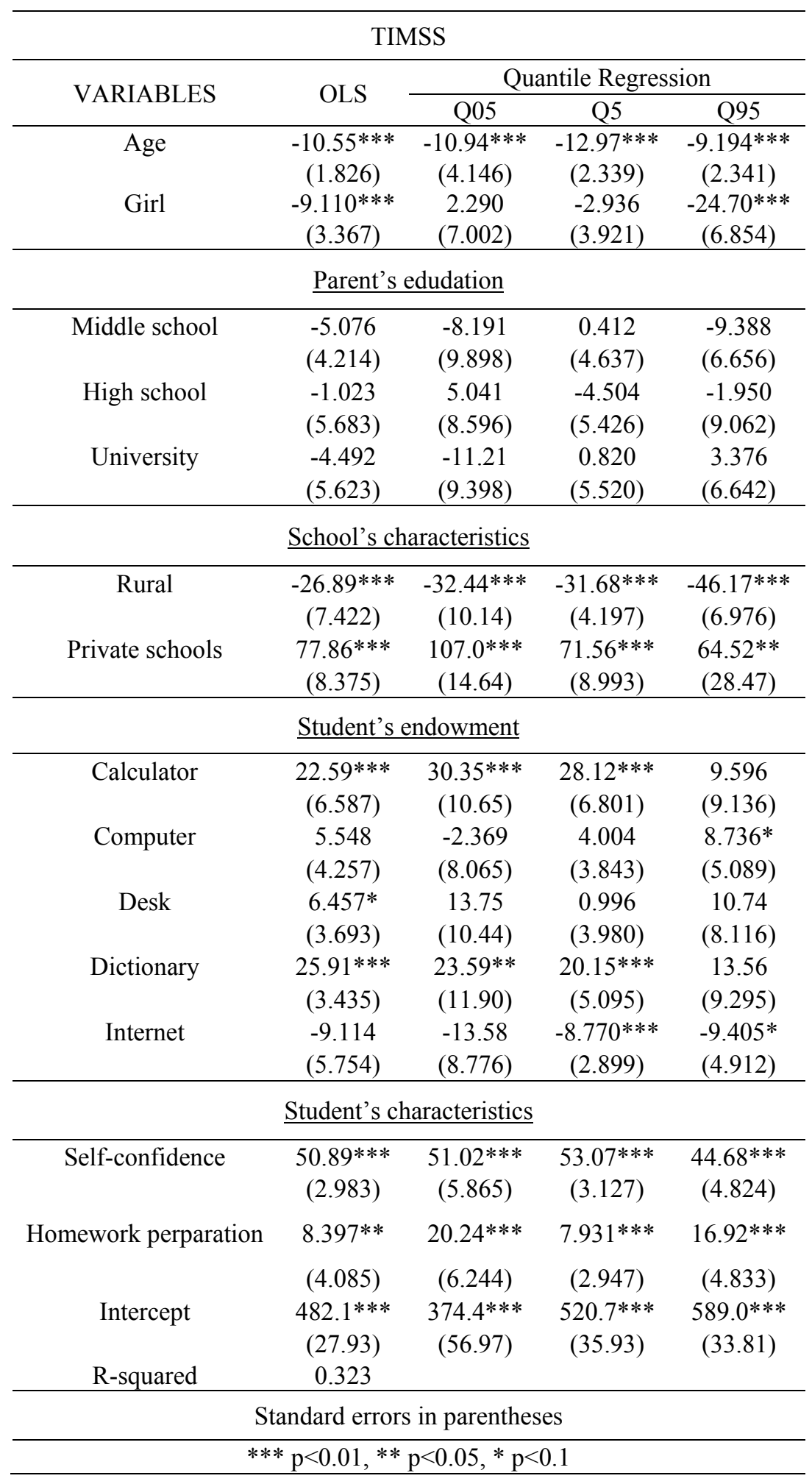

The school location impacts dramatically students' performance; however this impact varies heavily from a student to another, in a performance basis. This fact is observed in many developing countries such as Thailand (Lockheed, Fuller, \& Nyirongo, 1989). Moreover, the quantile regressions show that the rural effect on students' performance, with low or median performance, is estimated respectively at -32.44 and -31.68 . Unfortunately, the huge gap is observed among the most performing students, the difference in the score is estimated at 46 points. 
The widest gap is observed when one separates between public and private schools. Private students outperform those enrolled in public schools in each category. For students with low performance and median performance, the difference is estimated respectively at 107 and 71.56, while for the most performing students the gap amounts only 64.52 points. Thus, the gap between private and public schools tends to decrease as performance increases. Note here that low performing students can improve largely their performance if enrolled in private school; however, since the access to this kind of schools is not affordable for a lot of households, the equality of opportunities is definitively weakened.

Regarding students characteristics, it appears that both variables affect significantly and positively the score. One can imagine that the effect of self-confidence would increase as student's performance increase, but it's not the case. Self-confident median students are the one who beneficiate the more, the coefficient are estimated at 53.07. When the student has low performance, self-confidence is awarded by 51.02 points while the coefficient for good student is estimated only at 44.68 points. On the other side, homework preparation seems to be more effective among good and poor students than it is among median students.

In order to investigate more the relation between covariates and the dependent variables, one can rely upon a graphic analysis. The graphics showed below correspond to the different coefficients estimated for each quantile while the horizontal line corresponds to the OLS estimation since the latter is supposed to be equal for the whole distribution. It is also important to note that the graphic analysis come only as a complement to the previous analysis based on table 4. Concerning the rural effect, it appears that the effect is less pronounced in the first half of the distribution while the positive effect of private school has a downward trend going from low quantiles to higher ones. However, self-confidence has a saw-tooth shape, and hence there is apparently no trend.
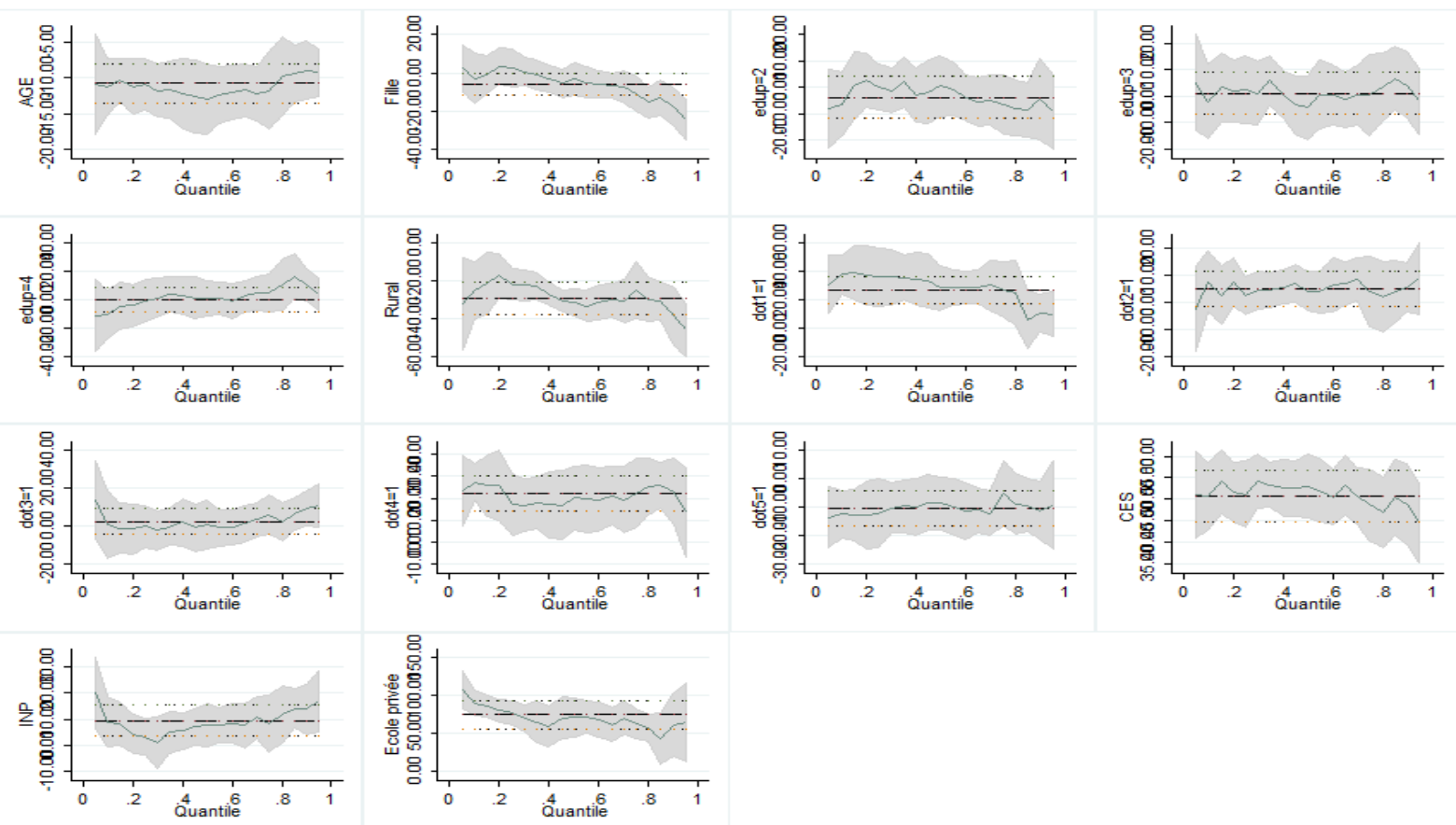

Figure 5. Coefficients estimated for each quantile

\section{Conclusion}

Although Morocco is showing, through these last years, a real will to improve its educational system, the results revealed by TIMSS and PIRLS give emphasis to several weaknesses of education in this country. This paper investigated the determinants of this low performance by using the quantile regression method. The latter revealed that a homogenous effect of covariates on the whole conditional distribution is seldom found. That is, several factors are affecting students differently according to their performance, which make the problematic more difficult. 
Furthermore, Morocco's educational system is by no means uniform, since there is a huge difference in performance whether the school is private or public, not to mention the gap between rural and urban areas. In other words, private schools outperform, by far, other types of schools while those located in rural areas have the lowest scores. Regarding rural schools, the students who suffer the most belong to the high performance category in mathematics, while in the case of reading; the median students are the ones that suffer the most. On the other hand, private schools present the same pattern, namely a downward trend, in mathematics as well as in reading.

The gender gap is the most outstanding example concerning how some factors can affect scores differently from a discipline to another. In mathematics, boys, generally, do better than girls; however this fact is inverted regarding reading. Moreover, parent's profession has a direct impact on reading ability, yet not in a homogeneous fashion through the whole conditional distribution. Students, who are generally doing well in school, seem only negatively affected when their parents have a tenuous job. When one or both parents have a full time job, no difference in scores is noticed. On the other side, poor students' score is only ameliorated when both parents have a full time job.

Throughout the elaboration of this paper, several problems were encountered mainly related to the quality of data. Even though some variables were wonderfully designed, such as teachers' variables, their use was, unfortunately, impossible since several missing data were noticed. Note that the latter was not missed at random, and hence no method can be reliable to fulfill these missing data. In addition, several variables in TIMSS are not present in PIRLS, which lets only a few room to comparisons. Hence, all these facts diminish dramatically the scope of the analysis, nonetheless, several aspects regarding quality of education were revealed.

Indeed, the main conclusions, which can be drawn from this research, give emphasis to the danger of centralized policies and also the danger of focusing objectives exclusively on a quantitative basis. Through this article, one can notice that several phenomena affect differently schools, disciplines and even students. Thus, a totally centralized policy, that occults school specificities and students characteristics, is likely deemed to failure. In order to achieve more accurate policies, it is important to implicate all the stakeholders (parents, unions, students), and providing more autonomy to regional departments, since the latter are supposed to be more aware of school's environment.

The fact that almost all developing countries are focused on quantity of schooling may have an hazardous effect on education. In fact, generalizing the access to a failing educational system can only amplify inequalities. It is worth noting that giving children access to school is one thing, teaching them values and knowledge is another. There are complementary, and hence government efforts should be oriented towards both sides of education, in order to achieve something more concrete. Unfortunately, Morocco's educational system became dichotomous in ways that there is two kind of education supply. The first one is public education providing a low quality and addressed to the majority of the population, meanwhile the second, which is private and more selective, provide a high quality education that can be comparable to some OECD countries. This situation leads generally to an amplified intergenerational inequality.

It is true that improving the quality of education is a hard task; however ignoring it would entail several social problems. Based on the findings, rural schools should receive a specific attention in order to diminish the existing gap between those school and urban schools. In order to upgrade the quality of education, many paths can be explored.

\section{References}

Aghion, P., \& Howitt, P. (1998). Endogenous Growth Theory. Cambridge, MA: MIT Press.

Akoue, M. (2007). Le redoublement des filles dans les classes de 3ème des écoles secondaires de Libreville au Gabon. Faculté des Sciences de l'Education, Université Laval.

Altinok, N. (2007). Essais sur la qualité de l'éducation et la croissance économique (PhD thesis, Université Bourgogne, Dijon).

Amaghouss, J., \& Ibourk A. (2012). Measuring Education Inequalities: Concentration and Dispersion-Based Approach-Lessons from Kuznets Curve in MENA Region. World Journal of Education, 2(6), 51-65. http://dx.doi.org/10.5430/wje.v2n6p51

Amaghouss, J., \& Ibourk, A. (2013a). Inequality in Education and Economic Growth: Empirical Investigation and Foundations - Evidence from MENA Region. International Journal of Economics and Finance, 5(2), 111-124. http://dx.doi.org/10.5539/ijef.v5n2p111 
Amaghouss, J., \& Ibourk, A. (2013b). Education and Economic Growth in the MENA Region: Some New Evidence. Journal of Economics and Sustainable Development, 4(8), 34-45.

Becker, G. S. (1964). Human Capital, A Theoretical and Empirical Analysis. Columbia University Press for the National Bureau of Economic Research, New York.

Barro, R. J. (1991). Economic Growth in a Cross Section of Countries. The Quarterly Journal of Economics, 106(2), 407-43. http://dx.doi.org/10.2307/2937943

Benhabib J., \& Spiegel M. (1994). The Role of Human Capital in Economic Development: Evidence from Aggregate Cross-country Data. Journal of Monetary Economics, 34(2), 143-173. http://dx.doi.org/10.1016/0304-3932(94)90047-7

Benhabib, J., \& Spiegel, M. M. (2005). Human capital and technology diffusion. In P. Aghion, \& S. Durlauf (Eds.), Handbook of Economic Growth (Vol. 22), Amsterdam: Elsevier, North-Holland.

Boudon, R. (1973). L'inégalité des chances. La mobilité sociale dans les sociétés industrielles. Paris: Armand Colin.

Bourdieu, P. (1966). L'école conservatrice: Les inégalités devant l'école et devant la culture. Revue Française de Sociologie, 7(3), 325-347. http://dx.doi.org/10.2307/3319132

Bourdieu, P., \& Passeron, J.-C. (1970). La reproduction. Eléments pour une théorie du système d'enseignement. Paris, Minuit.

Chernozhukov, V., \& Hansen, C. (2008). Instrumental Variable Quantile Regression: A Robust Inference Approach. Journal of Econometrics, 142(1), 379-398. http://dx.doi.org/10.1016/j.jeconom.2007.06.005

Denison, N. (1962). The sources of Economie Growth in the United States and the Alternatives before us. Supplementary paper, n 13. New York: Committee for Economic Development.

Durkheim, E. (1992). Éducation et sociologie. PUF, Paris.

Duru-Bellat, M. (2003). Inégalités sociales à l'école et politiques éducatives. UNESCO.

Hanushek, E. A., Kain, J. F. Markman, J. M., \& Rivkin, S. G. (2003). Does Peer Ability Affect Student Achievement? Journal of Applied Econometrics, 18(5), 527-544.

Hanushek, E., \& Wößmann. (2007). The role of education quality in economic growth. Policy Research Working Paper Series 4122, The World bank.

Hijri, N., Montmarquette, C., \& Mourji, F. (1995). Les déterminants des résultats scolaires: étude économétrique su la base d'enquêtes au Maroc. Revue d'économie du développement, 1.

Ibourk, A. (2009). La formation des adultes au Maroc. MEDA éducation et formation pur l'emploi (MEDA ETE) ETF.

Ibourk, A. (2011). Morocco: the challenges of employment, equal opportunities and moving out of informality. In Jobs, Freedom, and Social Justice: The Economic and Social Roots of the "Arab Spring", BIT, 2011.

Koenker, R. (2005). Quantile Regression. Cambridge UK: Cambridge University Press. http://dx.doi.org/10.1017/CBO9780511754098

Lazear, E. P. (2001). Educational Production. Quarterly Journal of Economics, 116(3), 777-803. http://dx.doi.org/10.1162/00335530152466232

Lazear, A., \& Edward, P. (2003). Teacher incentives. Swedish Economic Policy Review, 10(3), 179-214.

Le Bastard-Landrier, S. (2005). L'expérience subjective des élèves de seconde: Influence sur les résultats scolaires et les vœux d'orientation. L'orientation scolaire et professionnelle, 34(2), 143-164. http://dx.doi.org/10.4000/osp.368

Lockheed, M., \& Verspoor, A. (1991). Improving Primary Education in Developing Countries (p. 183). Washington, D.C.: Oxford University Press.

Maehr, M. L., Pintrich, P. R., \& Linnenbrink, E. A. (2002). Motivation and achievement. In R. Colwell, \& C. Richardson (Eds.), The new handbook of research on music teaching and learning (pp. 348-372). New York: Oxford University Press.

Mankiw, G. N., Romer, D., \& Weill, N. D. (1992). A contribution of the Empirics of Economic Growth. The Quaterly Journal of Economics, 107(2), 407-437. http://dx.doi.org/10.2307/2118477 
McIntosh, S., \& Vignoles, A. (2001). Measuring and assessing the impact of basic skills on labor market outcomes. Oxford Economic Papers, 53, 453-481. http://dx.doi.org/10.1093/oep/53.3.453

Mincer, J. (1958). Investment in Human Capital and Personal Income Distribution. The Journal of Political Economy, 66(4), 281-307. http://dx.doi.org/10.1086/258055

Mingat, A. (1991). Expliquer la variété des acquisitions au cours préparatoire: les rôles de l'enfant, la famille et l'école. Revue française de pédagogie, 95, 47-63. http://dx.doi.org/10.3406/rfp.1991.1355

Murnane, R. J., Willett, J. B., Duhaldeborde, Y., \& Tyler, J. H. (2000). How important are the cognitive skills of teenagers in predicting subsequent earnings? Journal of Policy Analysis and Management, 19(4), 547-568. http://dx.doi.org/10.1002/1520-6688(200023)19:4<547::AID-PAM2>3.0.CO;2-\#

Nelson, R., \& E. Phelps. (1966). Investment in Humans, Technological Diffusion and Economic Growth. American Economic Review, 61, 69-75.

Ouellet, R. (1987). Effets de l'organisation scolaire sur la réussite scolaire. Revue des sciences de l'éducation, 13(1), 85-97. http://dx.doi.org/10.1016/S0272-7757(00)00056-X

Psacharopoulos, G., \& Woodhall, M. (1988). L'analyse coûts-avantages de l'investissement en éducation (pp. 30-74). In L'éducation pour le développement. Une analyse des choix d'investissement. Paris: Economica.

Psacharopoulos, G. (1986). Returns to Education: A Further International Update and Implications. Journal of Human Resources, 20(4), 583-604. http://dx.doi.org/10.2307/145686

Psacharopoulos, G., \& Patrinos, H. A. (2004). Returns to investment in education: A further update. Education Economics, 12(2), 111-134. http://dx.doi.org/10.1080/0964529042000239140

Romer, P. M., (1990). Endogenous Technological Change. Journal of Political Economy, 98(5), 71-102. http://dx.doi.org/10.1086/261725

Suchaut, B. (2006). Analyse des acquisitions des élèves de l'enseignement secondaire en Algérie sur la base de l'enquête MLA II. Université de Bourgogne et Irédu-CNRS.

Schultz, T. W. (1997). Investment in Human Capital. New York: The Free Press.

Wößmann, L. (2003). Schooling Resources, Educational Institutions and Student Performance: The International Evidence. Oxford Bulletin of Economics and Statistics, 65(2), 117-170. http://dx.doi.org/10.1111/1468-0084.00045

\section{Copyrights}

Copyright for this article is retained by the author(s), with first publication rights granted to the journal.

This is an open-access article distributed under the terms and conditions of the Creative Commons Attribution license (http://creativecommons.org/licenses/by/3.0/). 